\title{
Teknologi Tepat Guna Pemurnian Minyak Kelapa Tradisional Di Desa Mengkalang Jambu Kabupaten Kubu Raya Kalimantan Barat
}

\author{
Maherawati*1 dan Iman Suswanto $^{2}$ \\ ${ }_{1}^{1}$ Prodi Teknologi Pangan Fakultas Pertanian, Universitas Tanjungpura Pontianak \\ ${ }^{2}$ Prodi Agroteknologi Fakultas Pertanian, Universitas Tanjungpura Pontianak \\ Jl. Prof.Dr. Hadari Nawawi Pontianak 78124 \\ *email: $\underline{\text { maherawati@faperta.untan.ac.id }}{ }^{1}$; $\underline{\text { man.suswanto@faperta.untan.ac.id }}^{2}$
}

\begin{abstract}
Traditional coconut oil has the potential to be developed into commercial oil. These community service activities are a) coconut oil production practices, $b$ ) introduction of coconut oil refining technology and c) assessment of people's perceptions of coconut oil production. The variables used are the process of making oil, product quality, technology transfer and people's motivation to make oil. Questionnaire data were analyzed with contingencies to show the close relationship between variables and community groups. The results of the activity showed that there were two ways of making traditional coconut oil, using fresh coconut milk and fermented coconut milk. The resulting oil is crude coconut oil with a characteristic rancid odor, dark color and not durable. The process of oil production is a variable that shows real differences between young and old groups, while other variables are not significantly different. As many as $75 \%$ of young group respondents stated that the process of making coconut oil at a somewhat difficult to difficult level. The close relationship between the respondent group and the process of making coconut oil has high accuracy, which is 0.64. Improving coconut oil manufacturing techniques with the refining process can be one way to improve quality and efforts to support the commercialization of traditional coconut oil.
\end{abstract}

Keywords: coconut oil, perception, refining technology

\begin{abstract}
Abstrak
Minyak kelapa tradisional mempunyai potensi untuk dikembangkan menjadi minyak komersial. Kegiatan pengabdian masyarakat berupa a) praktek produksi minyak kelapa; b) introduksi teknologi pemurnian minyak kelapa dan c) penilaian persepsi masyarakat terhadap pembuatan minyak kelapa. Variabel yang digunakan berupa proses pembuatan minyak, kualitas produk, transfer teknologi dan motivasi masyarakat untuk membuat minyak. Data kuesioner dianalisis dengan kontigensi untuk menujukkan keeratan hubungan variabel dengan kelompok masyarakat. Hasil kegiatan menunjukkan terdapat dua cara pembuatan minyak kelapa tradisonal, yaitu menggunakan santan segar dan santan fermentasi. Minyak yang dihasilkan berupa minyak mentah dengan ciri bau tengik, warna gelap dan tidak tahan lama. Proses pembuatan minyak merupakan variabel yang menunjukkan perbedaan nyata untuk kelompok muda dan orang tua, sedangkan variabel lainnya tidak berbeda nyata. Sebanyak $75 \%$ responden kelompok muda menyatakan bahwa proses pembuatan minyak kelapa pada tingkat agak sulit hingga sulit. Keeratan hubungan antara kelompok responden dengan proses pembuatan minyak kelapa mempunyai akurasi yang tinggi, yaitu 0,64. Perbaikan teknik pembuatan minyak kelapa dengan proses pemurnian dapat menjadi salah satu cara untuk perbaikan mutu dan upaya untuk mendukung komersialisasi minyak kelapa tradisional.
\end{abstract}

Kata kunci: minyak kelapa, persepsi, teknologi pemurnian

\section{PENDAHULUAN}

Tanaman kelapa merupakan salah satu tanaman perkebunan yang cukup banyak terdapat di Kalimantan Barat, berdasarkan data BPS tahun 2017 luas areal tanaman kelapa yang berkembang sebagai perkebunan rakyat sebesar 106.514 ha dengan produksi 73.982 ton (BPS, 2017). Bagi masyarakat Desa Mengkalang Jambu, kelapa merupakan sumber pendapatan sekaligus sebagai bagian dari budaya setempat. Kelapa ditanam di sekitar rumah atau kebun yang tidak jauh dari pemukiman. Kepemilikan lahan berkisar antara 2-5 ha/keluarga, dengan kerapatan tanaman 180 pohon/ha. Jenis kelapa biasa dikenal kelapa dalam dicirikan dengan ketinggian pohon mencapai $15 \mathrm{~m}$ dan umur produksi sampai 50 tahun. Produk akhir dapat 
berupa kelapa bulat, kopra maupun minyak goreng. Kelapa dapat dijual dalam bentuk kelapa bulat atau olahan kelapa berupa kopra dan minyak kelapa. Produk samping tanaman kelapa berupa sabut, tempurung, atau air kelapa belum dimanfaatkan secara optimal.

Masa lima tahun terakhir, perdagangan kelapa mengalami kemerosotan harga jual. Menurut Patty, dkk. (2019) harga jual kelapa yang rendah menyebabkan pendapatan petani kelapa juga rendah. Kondisi ini diperparah dengan banyaknya tanaman mati akibat serangan kumbang kelapa yang menyebabkan kematian ratusan hektar lahan pertanaman kelapa. Pada semester I tahun 2018 harga CPO (sawit) menurun sebesar 6,44\% menjadi RM 2.288/metrik ton. Penurunan harga minyak goreng internasional berdampak pada merosotnya harga kopra menjadi hanya Rp. 6000/kg. Kopra merupakan produk kelapa utama disamping produk lain berupa kelapa segar tua/muda serta minyak kelapa. Pada saat ini harga buah kelapa Rp. 500/butir, padahal untuk memperoleh 1 kg kopra diperlukan 4-6 butir kelapa. Rendahnya harga penjualan kopra menyebabkan kerugian petani kelapa di desa tersebut.

Selain itu, produksi minyak kelapa tradisional hanya dikonsumsi terbatas oleh masyarakat. Hal ini berakibat pada kurang berkembangnya pengolahan minyak di masyarakat. Padahal sumber daya bahan baku kelapa melimpah, tetapi belum dapat mendongkrak perekonomian masyarakat. Menurut Salam dan Syahrizal (2018), melimpahnya ketersediaan bahan baku kelapa menjadi penyokong utama berdirinya unit pengolahan kelapa sehingga pengusaha tidak khawatir akan kekurangan bahan baku. Beberapa permasalahan pengolahan minyak kelapa di Desa Mengkalang Jambu adalah sebagai berikut: (1) kualitas minyak kelapa yang diproduksi masyarakat belum baik; (2) produksi minyak kelapa yang dijalankan secara tradisional skala rumah tangga dan belum bersifat komersial; (3) kendala perbaikan kualitas minyak kelapa masyarakat.

Perlu dilakukan upaya untuk mengatasi permasalahan tersebut di atas. Pengolahan minyak tradisional yang menjadi kekayaan budaya masyarakat setempat perlu diperkaya dengan introduksi teknologi baru sehingga dapat mengatasi kelemahan-kelemahan minyak kelapa tradisional. Teknologi yang dapat digunakan untuk meningkatkan kualitas minyak kelapa tradisional adalah pemurnian. Menurut Poli (2016) untuk memperoleh minyak yang bermutu baik, minyak kelapa harus dimurnikan dari bahan-bahan atau kotoran yang ada didalamnya. Zat-zat pengotor yang ada di dalam minyak berupa komponen yang tidak larut dalam minyak, suspensi koloid, dan komponen yang larut dalam minyak seperti asam lemak bebas, dan zat warna. Proses pemurnian minyak kelapa umumnya dilakukan secara komersial melalui tahapan-tahapandegumming, refining, bleaching ataupemucatan, deodorisasi atau penghilangan bau ( Ketaren, 1986; Sugiyono, 2007).

Pelaksanaan introduksi teknologi pada suatu produk tradisional membutuhkan kesiapan masyarakat sebagai pengguna teknologi. Perlu diperoleh persepsi masyarakat terhadap teknologi yang akan diperkenalkan sehingga menumbuhkan perilaku social yang mendukung pemanfaatan terknologi tersebut. Menurut Mappiere (2002), perilaku adalah cerminan dari segala tindakan untuk mencapai tujuan tertentu setelah melalui proses pengamatan, penilaian dan pengambilan keputusan. Oleh karena itu tujuan dari kegiatan ini adalah untuk mengamati persepsi masyarakat terhadap introduksi teknologi pemurnian untuk meningkatkan kualitas minyak kelapa. Dengan demikian diharapkan upaya perbaikan pengolahan minyak kelapa dapat menjadi sarana untuk memperbaiki ekonomi mayarakat.

\section{METODE}

Kegiatan pengabdian kepada masyarakat menggunakan metode a) praktek produksi bersama masyarakat; b) praktek teknologi pemurnian minyak dan c) penilaian produk minyak kelapa berdasarkan persepsi peserta kegiatan sebagai responden melalui kuesioner. Responden dibedakan berdasarkan kelompok umur, yaitu kelompok pemuda (umur $\leq 30$ 
tahun) dan kelompok orang tua (umur $>30$ tahun). Masing-masing responden memberikan penilaian terhadap beberapa variabel terkait proses pembuatan minyak, kualitas produk, transfer teknologi, dan motivasi dengan nilai tertentu seperti yang dijelaskan pada Tabel 1.

Penilaian menggunakan kategori 1= mudah/buruk/dekat/jarang; kategori $2=$ sedang/kadang; dan kategori $3=$ sulit/baik/jauh/sering. Penilaian ditentukan berdasarkan akumulasi nilai dari responden.

Selanjutnya data yang telah terisi ditabulasi untuk dianalisis untuk memperoleh koefisien kontingensi dan uji Chi square taraf signifikansi 5\%. Derajat keakuratan model berupa besarnya hubungan antara golongan usia masyarakat dengan variabel-variabel pengamatan diuji dengan membandingkan nilai $\mathrm{C}$ dengan koefisien kontingensi maksimum $\left(\mathrm{C}_{\max }\right)$ dengan rumus sebagai berikut:

$$
c_{\max }=\frac{\sqrt{m-1}}{m}
$$

Keterangan: $\mathrm{m}=$ banyaknya kategori yang digunakan

Tabel 1. Kuesioner sebagai variabel dalam kegiatan pembuatan minyak kelapa tradisional

\begin{tabular}{clc}
\hline No & \multicolumn{1}{c}{ Variabel } & Harkat/Kategori \\
\hline 1 & Proses pembuatan minyak, dengan & \\
& komponen penilaian: & \\
& - pemilihan kelapa, & 1. mudah; 2. Sedang; \\
& - pengupasan, & \\
& - pemarutan, & \\
& - pemerasan dan & \\
& - pemasakan. & \\
2 & Kualitas produk, dengan komponen \\
& penilaian: & \\
& - penampilan, & 1. buruk; 2. Sedang; \\
& - keawetan, & dan 3. Baik \\
& - hasil gorengan, & \\
& - bau minyak & \\
& - rasa. & \\
& Transfer Teknologi pembuatan & \\
& minyak kelapa, dengan komponen & \\
penilaian: & 1. dekat; 2. Sedang; dan \\
& - Keluarga; & 3. Jauh \\
& - Sekolah; dan & \\
- Media elektronik & Motivasi pembuatan minyak kelapa, & 1. jarang; 2. Kadang; \\
dengan komponen penilaian: & dan 3. Sering \\
& - Acara tertentu & \\
- Kebutuhan sendiri &
\end{tabular}

Derajat keakuratan berguna sebagai pertimbangan untuk digunakan pada kondisi real di lapangan sesuai dengan pendapat Sudjana (1996) sebagai berikut: 0,9-1,00 = model memiliki akurasi sangat tinggi; $0,5-0,89=$ model memiliki akurasi tinggi; $0,21-0,49=$ model memiliki akurasi sedang; $<0,21=$ model memiliki akurasi rendah. 


\section{HASIL DAN PEMBAHASAN}

Sebelum dilakukan praktek produksi pembuatan minyak kelapa tradisional, terlebih dahulu dilakukan sosialisasi program. Setelah masyarakat paham dengan program yang akan dilakukan maka dilanjutkan dengan praktek pembuatan minyak kelapa. Suasana sosialisasi dan praktek produksi minyak kelapa bersama masyarakat dapat dilihat pada Gambar 1.

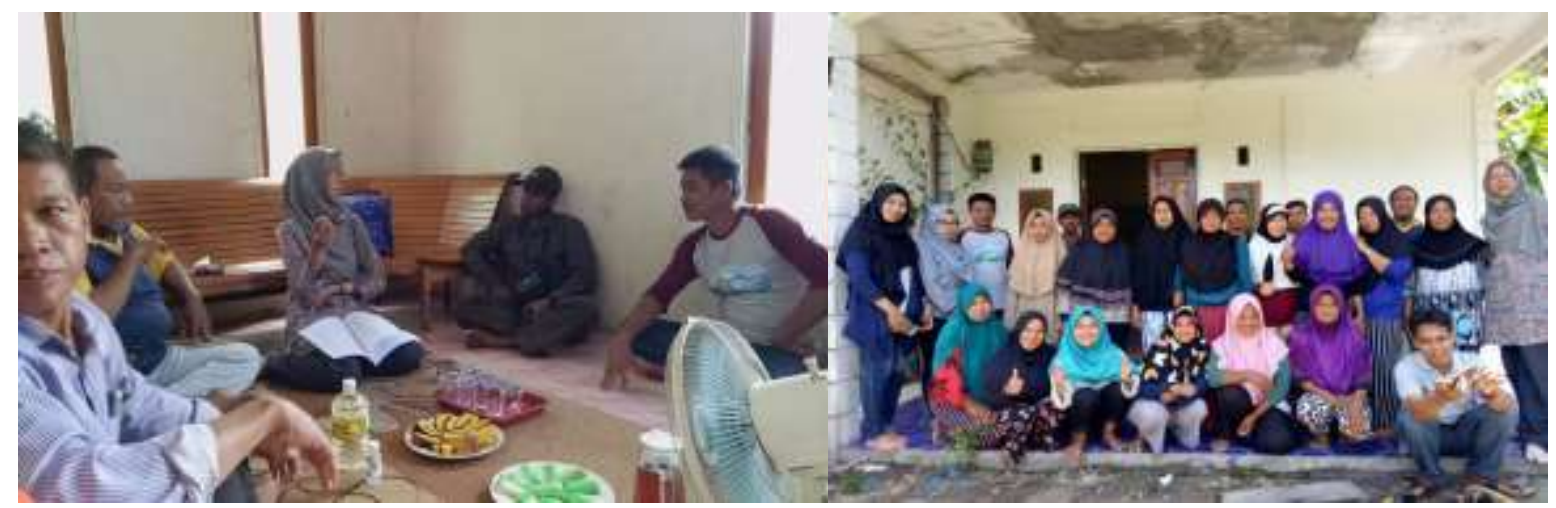

(a)

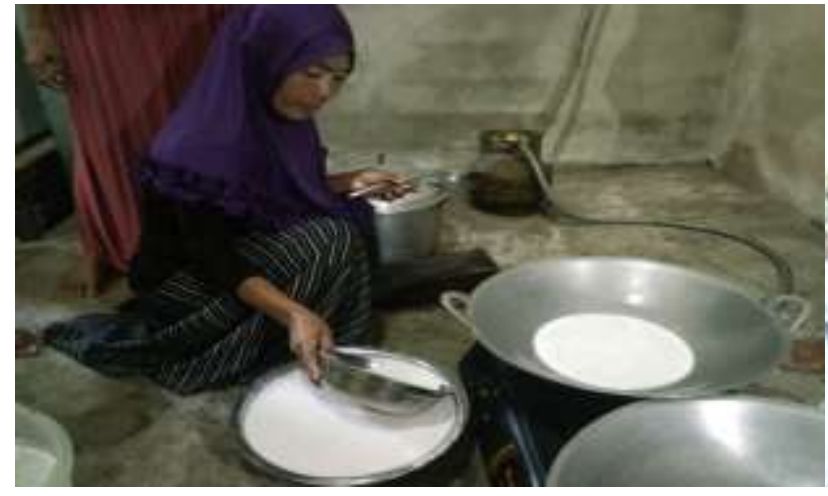

(c) (b)

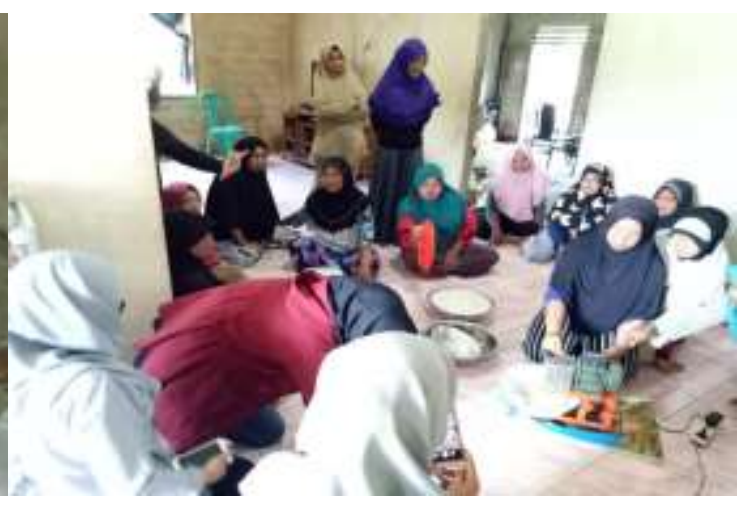

(d)

Gambar 1. Suasana sosialisasi program (a,b) dan praktek pembuatan minyak kelapa (c,d)

Pembuatan minyak tradisional di Desa Mengkalang Jambu ada dua cara pembuatan yaitu dengan santan segar dan santan yang dimalamkan (santan fermentasi). Kedua cara tersebut memberi hasil berupa minyak mentah (crude coconut oil) yang memiliki aroma khas kelapa sangat kuat dan tidak tahan lama. Hasil pembuatan minyak dapat dilihat pada Gambar 2 . Minyak mentah kemudian dimurnikan dengan teknologi pemurnian sederhana. Minyak yang dihasilkan setelah pemurnian kemudian diamati dan dibandingkan dengan minyak sebelum pemurnian. Hasil pengamatan yang diperoleh dapat dilihat pada Tabel 3.

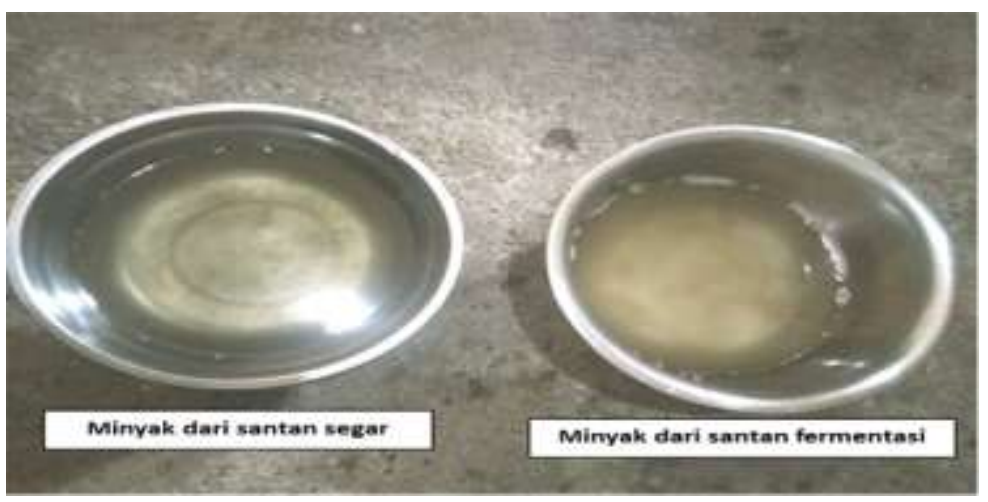

Gambar 2. Minyak kelapa mentah dari bahan yang berbeda 
Tabel 3. Karakteristik fisik minyak kelapa tradisional dan setelah dilakukan pemurnian

\begin{tabular}{lccc}
\hline \multirow{2}{*}{ Karakter } & \multicolumn{2}{c}{ Bahan dasar } & Hasil Pemurnian \\
\cline { 2 - 3 } & Santan segar & Santan fermentasi & \\
\hline Warna & agak coklat & coklat gelap & jernih \\
Bau & khas kelapa & agak tengik & khas kelapa \\
Rasa & gurih & ada rasa masam & gurih \\
Lama pemanasan & $30-35$ menit, & 20 menit, suhu \pm & - \\
& suhu $\pm 100^{\circ} \mathrm{C}$ & $100{ }^{\circ} \mathrm{C}$ & \\
Banyaknya & $360 \mathrm{ml}$ & $400 \mathrm{ml}$ & Rendemen $\pm 95 \%$ \\
minyak & & & \\
\hline
\end{tabular}

Setiaji \& Prayugo (2006) menyatakan bahwa pembuatan minyak kelapa dengan pemanasan mencapai lebih dari $100^{\circ} \mathrm{C}$ akan menghasilkan minyak kualitas rendah disebabkan oleh kerusakan protein, lemak dan antioksidan. Dampak dari pemanasan tinggi juga menyebabkan warna minyak menjadi coklat dan tidak tahan lama. Minyak yang berwarna gelap kurang disukai konsumen. Pembuatan minyak kelapa dari santan fermentasi menghasilkan minyak yang berwarna lebih gelap, selain itu minyak mempunyai rasa asam. Namun pembuatan minyak kelapa menggunakan santan fermentasi lebih disukai karena membutuhkan waktu pemanasan yang lebih cepat dibandingkan menggunakan santan segar.

Selanjutnya dilakukan introduksi teknologi pemurnian minyak. Teknologi tepat guna pemurnian minyak kelapa ini merupakan hasil penelitian yang telah dilakukan oleh mahasiswa dan dosen program studi Ilmu dan Teknologi Pangan Universitas Tanjungpura. Adapun metoda yang digunakan berupa proses netralisasi (menggunakan larutan $\mathrm{NaOH} \mathrm{0,96 \% ),} \mathrm{degumming}$ (menggunakan garam), dan filtrasi (menggunakan kain saring). Cara ini dianggap mudah dan aman diterapkan di tingkat masyarakat.

Hasil pemurnian minyak kelapa tradisional menunjukkan hasil yang memuaskan dan secara fisik terlihat perbedaan warna. Sebelum pemurnian, warna minyak kelapa cenderung gelap dan berbau menyengat khas kelapa. Setelah pemurnian, warna minyak menjadi lebih jernih dan bau menyengat berkurang. Secara fisik terlihat perbedaan warna yang sangat berbeda pada minyak setelah pemurnian. Warna minyak menjadi jauh lebih jernih dibandingkan sebelum pemurnian seperti dapat dilihat pada Gambar 3.

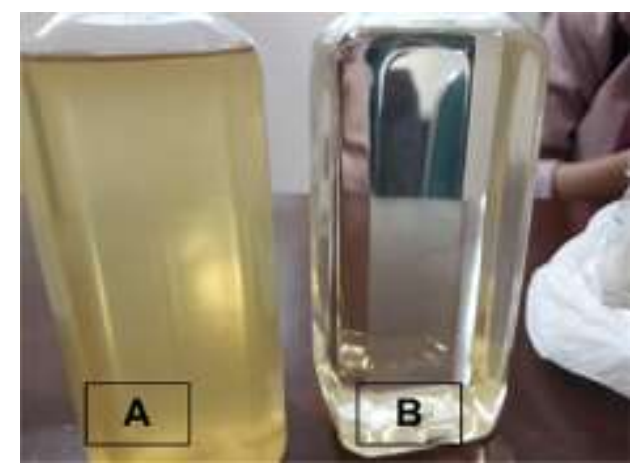

Gambar 3. Perbedaan visual minyak kelapa tradisional

(A) sebelum dan (B) sesudah proses pemurnian

Setelah melakukan proses pemurnian, dilanjutkan dengan penilaian persepsi masyarakat terhadap introduksi teknologi yang telah dilakukan. Hasil kuesioner diuji kontingensi dengan hasil seperti pada Tabel 4.

Hasil uji statistik dari semua variabel yang diamati pada Tabel 4 menunjukkan bahwa terdapat perbedaan nyata antara persepsi kelompok muda dan orang tua dalam proses pembuatan minyak kelapa. Sedangkan persepsi masyarakat tentang kualitas minyak, transfer 
teknologi, dan motivasi dalam produksi minyak tidak menunjukkan perbedaan yang nyata antara kelompok muda dan orang tua. Hasil analisis Chi-square kategori proses pembuatan minyak lebih diperjelas dengan data responden masing-masing kelompok masyarakat terhadap tingkat kesulitan proses pembuatan minyak pada Tabel 5.

Tabel 4. Hasil analisis variabel dengan tabulasi silang kontingensi dan perbandingan nilai $\mathrm{C} / \mathrm{C}_{\max }$

\begin{tabular}{lcccc}
\hline Variabel & $\begin{array}{c}\text { probabilitas } \\
\text { chi-sq }\end{array}$ & $\begin{array}{c}\text { koefisien } \\
\text { kontingensi (C) }\end{array}$ & $\mathrm{C}_{\max }$ & $\mathrm{C} / \mathrm{C}_{\max }$ \\
\hline Pembuatan Minyak & $0,02^{*}$ & 0,52 & 0,816 & 0,64 \\
Kualitas Minyak & 0,82 & 0,14 & 0,816 & 0,17 \\
Transfer Teknologi & 0,09 & 0,43 & 0,816 & 0,53 \\
Motivasi & 0,42 & 0,28 & 0,816 & 0,34 \\
\hline
\end{tabular}

Keterangan: * signifikan berdasarkan uji Chi sq pada taraf kepercayaan 95\%

Tabel 5. Data responden persepsi golongan masyarakat terhadap tingkat kesulitan proses pembuatan minyak kelapa secara tradisional

\begin{tabular}{lccc}
\hline \multirow{2}{*}{$\begin{array}{l}\text { Kelompok } \\
\text { Masyarakat }\end{array}$} & \multicolumn{3}{c}{ Persepsi tingkat kesulitan responden } \\
& \multicolumn{3}{c}{$(\%)$} \\
\hline Muda & 1. mudah & 2. sedang & 3. sulit \\
\hline Orang Tua & 23,08 & 38,46 & 38,46 \\
\hline
\end{tabular}

Proses pembuatan minyak kelapa melewati beberapa tahap mulai dari penyediaan bahan baku, pengupasan, pemecahan kelapa, pemarutan, pemerasan dan akhirnya pemisahan menjadi minyak dengan pemanasan. Proses yang panjang ternyata dianggap sebagai hal yang sulit bagi kelompok muda. Kegiatan pembuatan minyak kelapa tradisonal dianggap agak sulit hingga sulit oleh lebih dari 75\% responden kelompok muda, dan sisanya 23\% menganggap pembuatan kelapa secara tradisional mudah. Di lain pihak, dari kelompok orang tua menyatakan lebih dari $85 \%$ menganggap proses pembuatan minyak kelapa dlam kategori mudah.

Persepsi memegang peran penting bagi pengembangan ekonomi berbasis tradisi lokal. Keakurasian model hubungan kelompok masyarakat dengan proses pembuatan minyak secara tradisional ini mempunyai nilai 0,64 atau masuk dalam kategori akurasi model tinggi (Sudjana, 1996). Berdasarkan hal tersebut, berarti orang tua memegang peranan penting sebagai pelaku dalam pembuatan minyak kelapa secara tradisional. Hal ini diduga proses pembuatan minyak kelapa sudah menjadi kebiasaan yang dipertahankan secara turuntemurun dari beberapa generasi sebelumnya. Bagi kelompok orang tua, pembuatan minyak kelapa sudah menjadi rutinitas sehingga kegiatan ini tidak dianggap sebagai beban. Di lain pihak, bagi kelompok muda pembuatan minyak kelapa tradisional dianggap sebagai beban dan tidak relevan karena pemenuhan kebutuhan minyak dapat diperoleh dari minyak komersial yang banyak tersedia di warung/toko. Cara pembuatan yang membutuhkan waktu cukup lama dalam persiapan dan pengolahan juga menjadi faktor yang menentukan persepsi kelompok muda tentang kesulitan proses pembuatan minyak kelapa.

Lebih lanjut pada Tabel 4 menyatakan bahwa transfer teknologi pembuatan minyak dari dua kelompok masyarakat diperoleh dengan cara yang sama. Akurasi model hubungan kelompok usia dengan transfer teknologi mempunyai nilai 0,53 termasuk dalam hunungan yang akurasinya tinggi (Sudjana, 1996). Pengetahuan teknologi pembuatan minyak diperoleh secara turun-temurun, baik golongan orang tua maupun muda. Transfer teknologi secara turun-temurun dianggap efektif karena keberadaanya akhirnya menjadi budaya. Sebagian besar masyarakat mengenal dengan baik teknologi pembuatan minyak. Hal yang sama juga 
ditunjukkan pada kesamaan motivasi kelompok tua dan muda dalam pembuatan minyak. Hal ini berdampak pada keberlangsungan pembuatan minyak secara tradisional, karena selama ini pembuatan minyak kelapa hanya terbatas untuk kebutuhan sendiri baik untuk pemenuhan kebutuhan sehari-hari maupun pada acara keluarga seperti pernikahan dan lain-lain. Belum pernah dipikirkan untuk menjadikan minyak kelapa sebagai barang komersial yang dapat menjadi sumber pendapatan keluarga. Masyarakat tidak pernah menduga bahwa minyak kelapa tradisional dapat mempunyai kualitas seperti minyak sawit yang sudah dijual di tokotoko.

Berdasarkan hasil pengujian persepsi masyarakat, pembuatan minyak kelapa di Desa mengkalang Jambu dapat mempertahankan cirinya sebagai suatu produk tradisional karena keberadaanya tetap terjaga disebabkan oleh 2 faktor penting yaitu adanya hubungan yang erat antara teknologi dengan masyarakat. Kedua ciri tersebut diwakili oleh variabel pembuatan minyak dan transfer teknologi yang berturut-turut memiliki keakurasian model sebesar 0,64 dan 0,53. Sementara keakurasian model pada variabel kualitas produksi dan motivasi masingmasing berada pada ketegori akurasi sedang dan rendah.

Ciri produk tradisional adalah segala tindakan yang dipraktekkan oleh masyarakat tanpa mempertimbangkan sifat komersial maupun kualitas. Dengan demikian pembuatan minyak kelapa tradisional dapat menjadi teknologi unggul/maju apabila diupayakan perbaikan mutu dengan teknologi lanjut dan tindakan komersialisasi/market oriented. Banyak contoh produk tradisional yang pada akhirnya dapat disejajarkan dengan bisnis internasional seperti jamu tradisional, furniture/anyaman rotan, bambu dan lain-lain. Hal ini tidak terlepas dari peran serta para pihak yang mampu menggabungkan teknologi tradisional dengan teknologi tepat guna berdasarkan hasil penelitian.

\section{KESIMPULAN}

Pembuatan minyak kelapa di Desa Mengkalang Jambu masih bersifat tradisional yang dicirikan dengan tetap dipraktekkan masyarakat meskipun teknologi kurang berkualitas dan tidak menguntungkan. Keeratan hubungan antara kelompok masyarakat dengan proses pembuatan minyak kelapa cukup tinggi. Kelompok muda menganggap pembuatan minyak dalam tingkat agak sulit hingga sulit, sehingga perlu perbaikan proses produksi agar keberlangsungan produksi minyak kelapa tradisional bisa dipertahankan. Perbaikan proses pembuatan minyak kelapa dilakukan yang dengan teknologi pemurnian menggunakan larutan

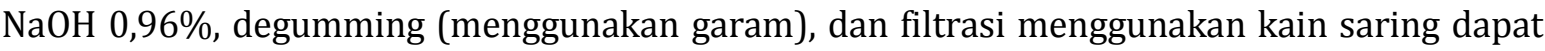
memperbaiki kualitas minyak kelapa tradisional. Peningkatan kualitas minyak perlu dukungan pembinaan dan peralatan mekanik untuk meningkatkan efisiensi produksi. Perbaikan teknik pembuatan minyak kelapa dengan proses pemurnian dapat menjadi salah satu cara untuk perbaikan mutu dan upaya untuk mendukung komersialisasi minyak kelapa tradisional.

\section{UCAPAN TERIMA KASIH}

Ucapan terima kasih disampaikan kepada Direktorat Jendral Pendidikan Tinggi Kementrian Pendidikan Riset dan Teknologi atas dana yang diberikan pada Skema Program Pengabdian Masyarakat sesuai Kontrak Pelaksanaan Program Pengabdian Masyarakat Nomor: 100/SP2H/DRPM/2019.

\section{DAFTAR PUSTAKA}

Badan Pusat Statistik. (2017). Statistik Pertanian Kalimantan Barat 2017. Pontianak: Badan Pusat Statistik. 
Patty, Z., Kastanja, A.Y., Manikome, N. (2019). Buah Naga sebagai Sumber Pendapatan Alternatif Petani Kelapa di Kecamatan Tobelo Timur. Dinamisia Jurnal Pengabdian Masyarakat Vol. 3 (spesial issue):117-124.

Poli, F. F. (2016). Pemurnian Minyak Kelapa dari Kopra Asap dengan Menggunakan Adsorben Arang Aktif dan Bentonit. Jurnal Riset Industri 10(3), 115- 124.

Ketaren, S. (1986). Pengantar Teknologi Minyak dan Lemak Pangan. Jakarta: UI Press.

Mappiere, A. (2002). Psikologi Remaja. Surabaya: Usaha Nasional.

Salam, A.H. dan Syahrizal. (2018). PKM Pengusaha Arang Tempurung Kelapa Desa Bantan Air Kecamatan Bantan Kabupaten Bengkalis Riau. Dinamisia Jurnal Pengabdian Masyarakat Vol 2(2): 278-282.

Sugiyono. (2007). Kajian Pemanfaatan Buah Kelapa Sebagai Bahan Baku Alternatif Minyak Goreng di Jawa Tengah, Seminar Badan Penelitian dan Pengembangan Provinsi Jawa Tengah, Semarang.

Setiaji, B. dan Prayugo, S. (2006). Membuat VCO berkualitas tinggi. Jakarta: Penebar Swadaya. Sudjana. (1996). Metoda Statistik. Bandung: Penerbit Tarsito.

Sugiyono. (2007). Kajian Pemanfaatan Buah Kelapa Sebagai Bahan Baku Alternatif Minyak Goreng di Jawa Tengah, Seminar Badan Penelitian dan Pengembangan Provinsi Jawa Tengah, Semarang. 